\title{
EFFECT OF EKALUX TOXICITY ON SELECTED PHYSIOLOGICAL PARAMETERS IN ANABAS TESTUDINEUS
}

\author{
RANJEeT, K. - Divya DAS, K. - FATHIMATh ShAmSiYA, M.P. - REShMi, K. \\ Post Graduate Department of Aquaculture and Fishery Microbiology \\ MES Ponnani College, Ponnani South, P.O., Malappuram (Dist) - 679 586, Kerala \\ (phone: 0494-2666094, fax: 0494-2669788) \\ *Corresponding author \\ e-mail: ranjeet.mes@gmail.com
}

(Received $12^{\text {th }}$ June 2011; accepted $5^{\text {th }}$ September 2013)

\begin{abstract}
Impact of short-term exposure of sub lethal concentration of organophosphate pesticides Ekalux on physiology of sub adults of Anabas testudineus in the Kol paddy fields of Central Kerala was studied. Results of the present study indicated that even short-term, exposure to Ekalux is detrimental to A. testudineus. Among the parameters that showed significant changes were heamatological parameters such as Hb, PCV, RBC count, and ESR. Cell morphology shifted from a normal elliptical shape after 24 $\mathrm{hr}$ to crenated or fringed and shrinked appearance at $15^{\text {th }}$ day of exposure. It was also seen that protein and amino acid concentration are clear indicators of immediate stress. Histopathological studies of liver showed hypertrophied hepatocytes with reduced number of normal cells after 15 days of exposure. The number of haematopoietic tissue was found to have declined in the kidney also in addition to increased number of melano-macrophage centres (MMC). However, once these fishes were reared in clear water, devoid of any pesticide for six months, values for $\mathrm{Hb}$, PCV, protein, amino acid and liver and renal tissues showed signs of revival. The present study depicts that severity of Ekalux toxicity to sub adults of Anabas testudineus is both dose and time dependant.
\end{abstract}

Keywords: Wetland, Ekalux, Anabas testudinues, Heamatology, Histopathology

\section{Introduction}

Kole lands are water logged paddy fields spread over Thrissur and Malappuram districts in Central Kerala. These Kole lands promote sustainable aquaculture practices through the integration of agriculture and pisciculture. But the application of persistent and toxic insecticides to the rice, the fish cultured in these fields are increasing getting contaminated by a variety of pesticide residues. Ekalux is an organophosphorous pesticide (Quinalphos) which is widely used in paddy fields of Malappuram district. Till date no data is available on the deleterious impact of Ekalux on the ecology of Kole lands in general and fishes in particular. Bioaccumulation of fish leads to major structural changes. They include histological structure changes, hematological changes as well as physiological stress, which are witnessed in the form of changes in biochemical constituents in the body of target organism (Grant \& Mehrle, 1973; Wedemeyer and Yasutake, 1977; Jagoe, 1996). Under the above background a study was carried out to determine the impact on the haematological, histological and biochemical constituents of freshwater fish Anabas testudineus when exposed to sub lethal concentration of Ekalux. This study warrants much attention to the fact the most of the paddy fields throughout the culture period act as sink for various pesticides. Fishes being inherent inhabitants of these ecosystems need to adapt to this rather hostile environments. Present study also investigates whether these negative effects of shortterm exposure to Ekalux could be nullified if the fishes were re-exposed to normal clear water. 


\section{Materials and Methods}

Live and healthy sub adult specimens of freshwater fish Anabas testudineus (Bloch) with an average weight of $20.25 \pm 0.29 \mathrm{~g}$ and length of $12.05 \pm 0.24 \mathrm{~cm}$ were collected from a local pond. A $96 \mathrm{hr} \mathrm{LC}_{50}$ for Ekalux on sub adults of Anabas testudineus was estimated following Yasmeen et al. (1991). For bioassay studies 48 healthy fishes of uniform size were selected and reared in four separate FRP tanks of $200 \mathrm{~L}$ capacity. The first set of tanks was not dosed with pesticide hence they were maintained as control tank (T1). In all the remaining tanks Ekalux was added at a concentration of $0.05 \mathrm{ppm}$. In T2, fishes were sacrificed at the end of $24 \mathrm{hr}$ period, while in T3 fishes were reared for 15 days before sacrificing for bioassay studies. In the last set of tanks (T4), after exposing the fishes to sub lethal concentrations for 15 days, fishes were transferred to freshwater devoid of any pesticide residue and reared for another 6 months. At the end of the clear water phase all the fishes were sacrificed for routine assessment. Throughout the experimental period the fishes fed with artificial feed twice daily. Tanks were aerated and water exchange was done every alternate day.

Haematological assay: Heamatological parameters assessed for the study were Packed Cell Volume (Microhaematocrit method) and Total RBC (Blaxhall and Dansel, 1973), Haemoglobin following Sahli's Acid Haemoglobin method (Hesser, 1960), Erythrocyte Sedimentation Rate (Das and Mukherjee, 2002) and Cell size following Wright's Giemsa staining method of Hesser (1960).

Biochemical studies: Biochemical constituents analyzed during the present study were Total protein (Lowry et al., 1951), Total amino acids by colorimetric method (Yemm and Cocking, 1955), DNA using diphenylamine method (Burton, 1956) and RNA following Orcinol reagent method (Hiroshi, 1962).

Histopathological examinations: Tissues examined during the present study included the liver and kidney. Tissues from fishes from four treatments were dissected out and preserved in 10\% Neutral Buffered Formalin (NBF), embedded and sectioned at $6 \mu$ thickness using microtome. The sections were then stained with Mayer's Hematoxylin and Eosin and mounted with DPX to be photographed at a magnification of $40 \mathrm{X}$.

Statistical Analysis: All the parameters observed were statistically evaluated following Gomez and Gomez (1984). Statistical analysis conducted included Analysis of Variance (ANOVA) and Duncun's Multiple Range Test (DMRT) following SPSS ver. 17.0 for Windows.

\section{Result and discussion}

\section{Determination of $L C_{50}$}

The $96 \mathrm{~h} \mathrm{LC}_{50}$ mean value of Ekalux for subadults of Anabas testudineus in the present study was found to be $1 \mathrm{ppm}$ (Table 1). The results showed that Ekalux is highly toxic to A. testiduneus and highest mortality of specimens was recorded at $4 \mathrm{ppm}$ concentration. 
Table 1. Percentage mortality of A. testudineus exposed to Ekalux

\begin{tabular}{|c|c|c|c|c|c|c|}
\hline \multirow{2}{*}{ Treatment } & \multirow{2}{*}{$\begin{array}{c}\text { Concentration } \\
\text { ppm }\end{array}$} & \multirow{2}{*}{$\begin{array}{c}\text { Fishes } \\
\text { exposed }\end{array}$} & \multicolumn{4}{|c|}{ Percentage of survival } \\
\hline & & & $24 \mathrm{hr}$ & $48 \mathrm{hr}$ & $72 \mathrm{hr}$ & $96 \mathrm{hr}$ \\
\hline 1 & 1 & 16 & 100 & 100 & 81 & 69 \\
\hline 2 & 2 & 16 & 90 & 88 & 56 & 43 \\
\hline 3 & 3 & 16 & 81 & 56 & 50 & 37 \\
\hline 4 & 4 & 16 & 81 & 50 & 50 & 31 \\
\hline
\end{tabular}

\section{Heamatological studies}

Result of the present study showed that there exists a discernable difference in all the haematological parameters studied among the treatments. However, these variations were mostly dependent on the exposure period of the Ekalux rather than the concentration of the pesticide itself. Results of one way analysis of variance (ANOVA) confirmed the above findings. Values of ANOVA showed a significant difference at less than $1 \%$ level $(\mathrm{P}<0.01 \%)$ for all the parameters observed i.e, haemoglobin $(\mathrm{F}=$ 15.391), Packed Cell Volume $(F=14.214), R B C$ count $(F=204.11)$ and Erythrocyte Sedimentation Rate $(\mathrm{F}=39.111)$. While analysing the performance of different haematological parameters following Duncan's Multiple Range Comparison Test (DMRT), it was observed that the value of haemoglobin were comparable in all the treatments except for T2 (24 hr exposure) (Table 2).

Table 2. Comparative evaluation of different haematological parameters of Anabas testudineus reared under different treatments

\begin{tabular}{|c|c|c|c|c|c|c|}
\hline Variable & Source & df & $\begin{array}{c}\text { Sum of } \\
\text { Squares }\end{array}$ & Mean Square & $\mathbf{F}$ & Sig. \\
\hline $\begin{array}{l}\text { Heamoglobin } \\
(\mathrm{Hb})\end{array}$ & $\begin{array}{c}\text { Between Treatments } \\
\text { Within Treatments } \\
\text { Total }\end{array}$ & $\begin{array}{c}3 \\
8 \\
11 \\
\end{array}$ & $\begin{array}{c}27.896 \\
4.833 \\
32.729 \\
\end{array}$ & $\begin{array}{l}9.299 \\
0.604\end{array}$ & 15.391 & 0.001 \\
\hline $\begin{array}{c}\text { Packed Cell } \\
\text { Volume (PCV) }\end{array}$ & $\begin{array}{c}\text { Between Treatments } \\
\text { Within Treatments } \\
\text { Total } \\
\end{array}$ & $\begin{array}{c}3 \\
8 \\
11 \\
\end{array}$ & $\begin{array}{c}387.333 \\
72.667 \\
460.00 \\
\end{array}$ & $\begin{array}{l}129.11 \\
9.083\end{array}$ & 14.214 & 0.001 \\
\hline $\begin{array}{l}\text { Red Blood } \\
\text { Cells (RBC) }\end{array}$ & $\begin{array}{c}\text { Between Treatments } \\
\text { Within Treatments } \\
\text { Total }\end{array}$ & $\begin{array}{c}3 \\
8 \\
11 \\
\end{array}$ & $\begin{array}{c}28.962 \\
4.552 \\
33.514 \\
\end{array}$ & $\begin{array}{l}9.654 \\
0.569\end{array}$ & 204.11 & 0.000 \\
\hline $\begin{array}{c}\text { Erythrocyte } \\
\text { Sedimentation } \\
\text { Rate (ESR) }\end{array}$ & $\begin{array}{c}\text { Between Treatments } \\
\text { Within Treatments } \\
\text { Total }\end{array}$ & $\begin{array}{c}3 \\
8 \\
11\end{array}$ & $\begin{array}{l}2.216 \\
0.232 \\
2.358\end{array}$ & $\begin{array}{l}0.709 \\
0.029\end{array}$ & 24.248 & 0.000 \\
\hline
\end{tabular}

This means the impact of pesticide is immediately felt in the concentration of $\mathrm{Hb}$, which later improves to a level similar to that of the control tanks (Fig 1A). However, the trend shown by PCV during such analysis was in total contrast to that of the $\mathrm{Hb}$. Once exposed to sub lethal concentrations of Ekalux, the corresponding PCV values differed significantly from that of the control tank (Table 2). However after being reared in clear water there was a gradual improvement in the values of PCV after 6 months (Fig 1B). Similar results were seen for RBC count as a clear difference exists among the control and treated tanks (Table 2). However, a noteworthy observation was that even after reintroducing the fishes to pesticide free environment there wasn't any significant 
improvement in the net RBC count (Fig 1C). ESR values of all the treatments differed significantly enabling them to be grouped under three different subsets (Table 5). The mean progression of ESR were in total contrast to the trend shown for PCV, whereby with time the ESR values increased but once the effect of pesticide was removed the values started to decline (Fig 1D).

Haemoglobin levels significantly decreased after 24 hour may be due to the disruption of the iron synthesizing machinery (Beena and Viswarajan, 1987). It may impair oxygen supply to various tissues, thus resulting in a slow metabolic rate and low energy production (Ahammed et al., 1999). The significant decrease may also be due to either an increase in the rate at which the $\mathrm{Hb}$ is destroyed or to a decrease in the rate of Hb synthesis (Reddy and Bashamohideen, 1989). Musa and Omoregie's (1999) reported similar results when fishes were exposed to polluted environment under laboratory conditions. Reduction in the RBC count of A. testudineus noticed in the present study could be due to the haemodilution resulting from impaired osmoregulation across the gill epithelium. Reduction of TEC may be suggestive of an appreciable decline in the haematopoiesis leading to various type of anaemia. Similar reduction of RBC were observed in Tilapia mossambica exposed to Sumithion and Sevin (Koundinya et al., 1979), Cyprinus carpio exposed to Cypermethrin (Reddy and Bashamohideen, 1989) and in Anabas testudineus exposed to Azodrin (Santhakumar et al., 1999). Decrease in the PCV may be attributed to the reduction of TEC. Decrease in the PCV may show the extent of shrinking cell size due to the insecticide intoxication (Ahmad et al., 1999). Naidu et al (1989) from a 24 hour short term study reported an increased in the $\mathrm{Hb}$ and PCV in Cyprinus carpio exposed to sub lethal concentration of Endosulfan. In the present investigation, even though, the RBC count decreased considerably initially, the fish tried to overcome the stressed condition by elevating the concentration of $\mathrm{Hb}$.

Studies on the cell morphology of erythrocytes exposed to sub lethal levels of Ekalux also showed varying degree of changes in external cell structure (Fig 3). When the fishes were exposed to pesticide the cell wall of erythrocytes of such fishes were crenated and showed distortion. Rather than maintaining the usual disc-like shape which the blood cell normally has (Fig 3A), RBC of exposed fished fishes showed small extendings (Fig 3B). The central area in these cells were considerably reduced (Fig 3C). Even after a revival phase of 6 months, similar manifestations in the external morphology of RBC were witnessed in fishes exposed to pesticides (Fig 3D). Some of the cells after $24 \mathrm{hr}$ exposure to Ekalux became elliptical in shape. With the increase in exposure period (15 days), the disappearance of the erythrocyte membrane, shrinkage of red blood cells and reduction in the size of the nucleus and erythrocyte matrix, were observed in these fishes. 
A. Haemoglobin (Hb)

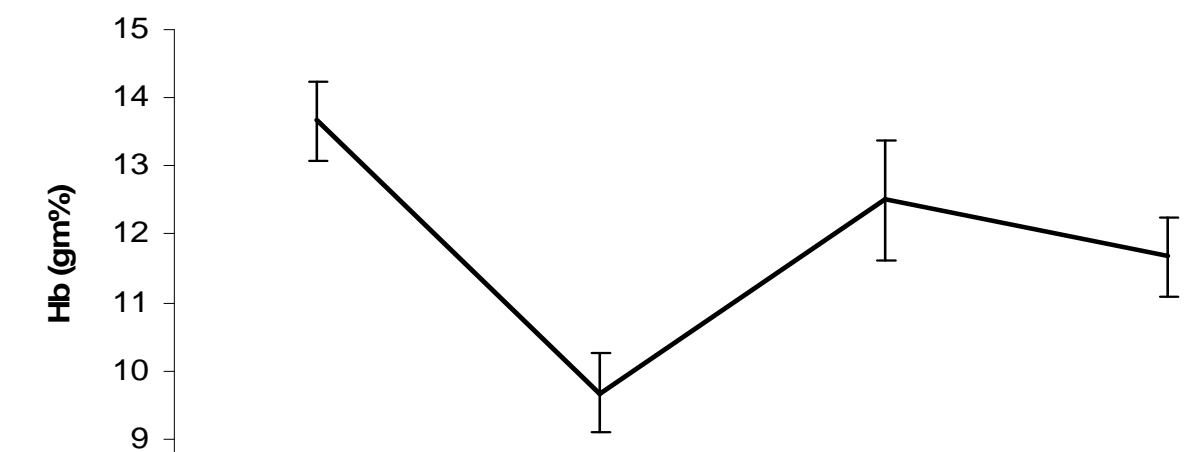

B. Packed Cell Volume (PCV)
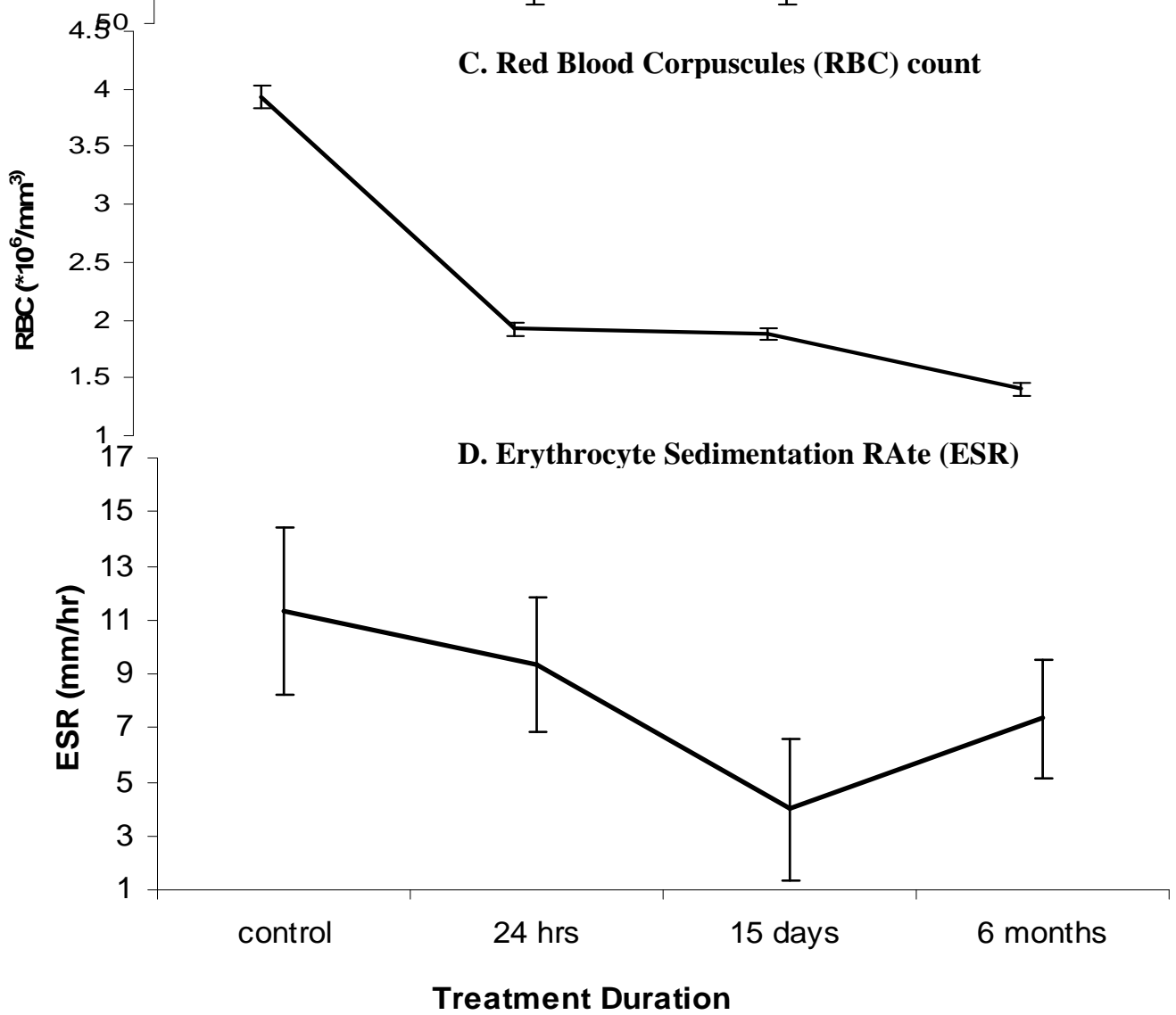

Figure 1. Variation in the Haematological parameters in Anabas testudineus 


\section{Biochemical studies}

The result of the present study clearly suggests that exposure of sublethal concentration of Ekalux in Anabas testudineus showed variations in protein, amino acid, DNA \& RNA (Table 3). The difference was highly significant $(\mathrm{P}<0.01)$ level for protein $(\mathrm{F}=18.560)$ and amino acid $(\mathrm{F}=8.111)$. While the difference for DNA $(\mathrm{F}=$ $4.513)$ \& RNA $(\mathrm{F}=4.919)$ were significant at $5 \%$ level. Result of DMRT test (Table 4) showed that once the fishes were exposed to Ekalux there was a rapid shift in the concentration of protein from the normal levels. However, when re-exposed to clear water there was a revival in the value of protein after six months (Fig 2A).

Table 3. Results of DMRT on difference in the concentration of Heamoglobin (Hb), Packed cell volume (PCV), RBC count and ESR rate

\begin{tabular}{c|c|c|c|c}
\hline Treatment & Hb & PCV & RBC & ESR \\
\hline T1 & $13.6667^{\mathbf{b}}$ & $67.3333^{\mathbf{b}}$ & $3.9300^{\mathbf{a}}$ & $2.1800^{\mathbf{a}}$ \\
T2 & $9.6670^{\mathbf{a}}$ & $54.3333^{\mathbf{a}}$ & $1.9200^{\mathbf{b}}$ & $2.7833^{\mathbf{b}}$ \\
T3 & $12.5000^{\mathbf{b}}$ & $52.6667^{\mathbf{a}}$ & $1.8800^{\mathbf{b}}$ & $3.2600^{\mathbf{b}}$ \\
T4 & $13.0000^{\mathbf{b}}$ & $57.6667^{\mathbf{a}}$ & $1.4000^{\mathbf{c}}$ & $2.3367^{\mathbf{c}}$ \\
\hline
\end{tabular}

Means for groups in homogeneous subsets are displayed.

Similarly for Amino acids also a sudden change in their concentration was discernible. However, the changes did not follow any particular trend (Fig 2B). While analysing the performance of DNA and RNA among the four treatments, it was observed that the impact of pesticide is more pronounced in these biochemical components. Interestingly, the concentration of both these parameters increased substantially as soon as the fishes came in contact with Ekalux. In the case of DNA (Table 4) the values were highest at 15 day interval following which they started to attain a normal level slowly when they were prolongingly exposed to normal conditions (6 months). This shift is more clearly illustrated in Fig 2C. However for RNA although the trend was similar to that of DNA (Fig 2D), results of DMRT suggest that once exposed to even sub lethal concentration of Ekalux, the values never revived to normal level (Table 5). Hence, RNA values can be considered as good indicators for assessing the impact of pesticide on the biochemical composition of fishes.

A fall in muscle protein is indicative of reduced protein synthesis and low assimilation of food and low amino acid uptake for protein synthesis. Similar results were documented by Murty and Devi (1982) and Narayan Ram and Sathyanesan (1986). The depletion in total protein content may be due to augmented proteolysis and possible utilization of their product for metabolic purposes as reported by (Ravinder and Suryanaraya, 1988). Decreased total protein level was observed in the muscle and liver tissue of the freshwater teleost fish C. fascitus exposed to sublethal dose of Malathion are Carbaryl pesticides (Tripathi and Singh, 2003). The present study suggests that level of total amino acid after exposure to Ekalux was higher than compared with control group. Protein degradation, resulting in elevation of total amino acid level may be a reason as noted in B. gueirini exposed to Endosulfan by Reddy et al. (1991). 


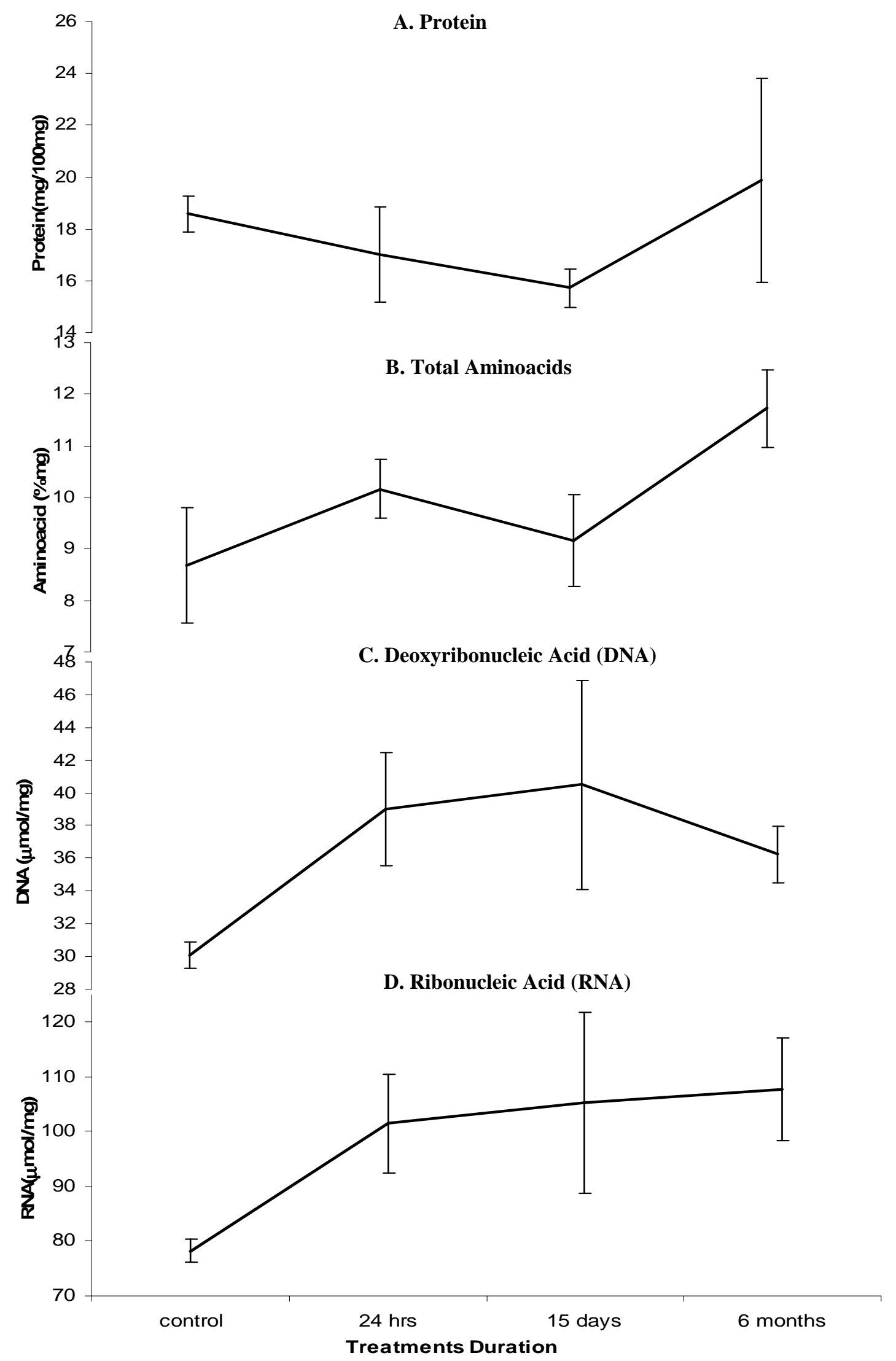

Figure 2. Variation in the Biochemical parameters in Anabas testudineus

APPLIED ECOLOGY AND ENVIRONMENTAL RESEARCH 11(4): 569-580. http://www.ecology.uni-corvinus.hu • ISSN 15891623 (Print) • ISSN 17850037 (Online) (c) 2013, ALÖKI Kft., Budapest, Hungary 
Table 4. Comparative evaluation of different biochemical parameters of Anabas testudineus reared under different treatments

\begin{tabular}{c|c|c|c|c|c|c}
\hline Variables & Source & df & $\begin{array}{c}\text { Sum of } \\
\text { squares }\end{array}$ & Mean squares & F & Sig. \\
\hline \multirow{3}{*}{ Protein } & Between Treatments & 3 & 58.790 & 19.597 & 18.560 & .001 \\
& Within Treatments & 8 & 8.447 & 1.056 & & \\
& Total & 11 & 67.236 & & & \\
Amino acid & Between Treatments & 3 & 13.409 & 4.470 & 8.111 & .008 \\
& Within Treatments & 8 & 4.408 & 0.551 & & \\
& Total & 11 & 17.817 & & & \\
DNA & Between Treatments & 3 & 191.191 & 63.730 & 4.513 & .039 \\
& Within Treatments & 8 & 112.980 & 14.122 & & \\
& Total & 11 & 304.170 & & & \\
RNA & Between Treatments & 3 & 1658.937 & 552.979 & 4.919 & .032 \\
& Within Treatments & 8 & 899.378 & 112.422 & & \\
& Total & 11 & 2558.315 & & & \\
\hline
\end{tabular}

Table 5. Results of DMRT on difference in the concentration of Protein, Total Amino acids, DNA and RNA

\begin{tabular}{c|c|c|c|c}
\hline Treatment & Protein & Amino acid & DNA & RNA \\
\hline T1 & $19.2600^{\mathbf{b}}$ & $10.3433^{\mathbf{a}}$ & $30.0667^{\mathbf{a}}$ & $78.1733^{\mathbf{a}}$ \\
T2 & $16.3500^{\mathbf{a}}$ & $9.1600^{\mathbf{a}}$ & $39.0167^{\mathbf{b}}$ & $101.4467^{\mathbf{b}}$ \\
T3 & $15.7200^{\mathbf{a}}$ & $9.1500^{\mathbf{a}}$ & $40.4933^{\mathbf{b}}$ & $105.2833^{\mathbf{b}}$ \\
T4 & $21.1867^{\mathbf{b}}$ & $11.7200^{\mathbf{b}}$ & $36.2333^{\mathbf{b}}$ & $107.7500^{\mathbf{b}}$ \\
\hline
\end{tabular}

Means for groups in homogeneous subsets are displayed.

\section{Histopathological studies}

Histological differences in the liver and renal tissues of fishes exposed to sublethal concentration of Ekalux are depicted in Fig. 4. In the present study some of the significant lesions were observed in liver and kidney exposed to Ekalux only after 15 days (Fig 4B). The liver had a low number of hepatocytes and necrotic lesions over the tissue. At sublethal concentration, an increased number of melanomacrophage centres with decreased amount of heamatopoietic tissue were observed in the kidney of $A$. testudineus. This is in total contrast to those observed in control groups were only loose mass of cells could be seen (Fig 4A). However, after reintroducing to normal environment for a period of 6 months, there was signs of tissue revival (Fig 4C). The hepatocytes appeared normal and could be compared to those of the control tanks. The haematopoietic tissue increased to normal levels in the kidneys of these fishes and the melanomacrophage centres decreased considerably, which are an indicator that at least 6 months of buffer period is required for tissue to regain its original form for a short-term exposure to Ekalux. 
A.
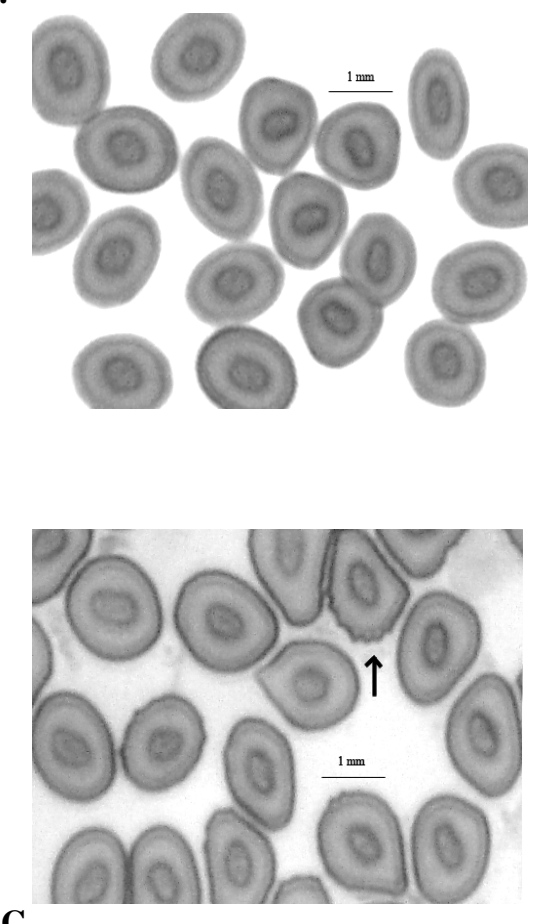

C.

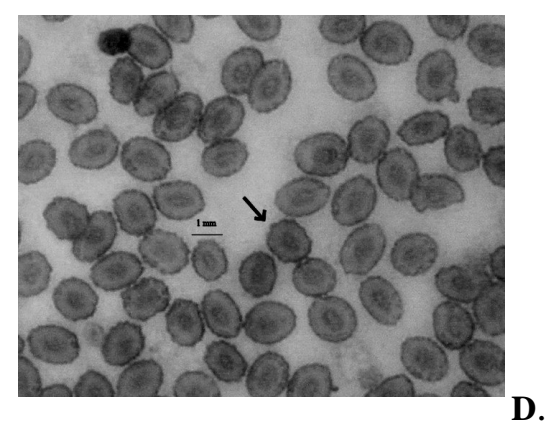

B.

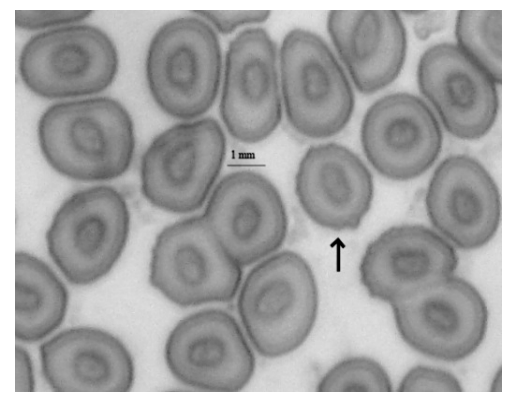

D.

Figure 3. Morphological Changes of Blood Cells under Different Treatments (A. Control, B. 24 Hour, C. 15 Days, D. 6 Months

In the present study, some of lesions found in liver and kidney related to exposure to Ekalux at sublethal concentration. The morphological lesions are mainly associated with hepatocytes. These lesions include hypertrophy of the hepatic cells and their reduced number. Sastry et al. (1979) stated that the sublethal concentrations of Endrin produced swollen hepatic cells, liver chord disarray, necrosis and vacoulation of cytoplasm in the liver of Channa punctatus. Hyperplasia and hypertrophy of the hepatic cells were the most notable features found by Abraham et al. (2003) in the liver of Anabas testudineus treated with Neemax. Hence the cells may become larger in size and to meet the requirement, cells proliferate much faster. Endosulfan exposure to rainbow trout revealed similar lesions, necrotic hepatocytes, vacuolar dystrophy and hypertrophy of hepatocytes and enlarged hepatic perisinusoidal areas (Altinok and Capkin, 2007). The results of histopathological investigations of renals tissues showed increased amount of melanomacrophages with reduced number of hematopoietic cells in kidney tissue similar to that reported by Capkin et al. (2006). Deteriorated levels of cell structure were prominent with greater exposure to pesticide in the present study also. Observations made herewith were closely related to marked pathological changes such as highly degenerative changes in hematopoietic tissue, cloudy swelling in renal tubules, cellular hypertrophy and granular cytoplasm as reported by Butchiram et al. (2009) in C punctatus when exposed to sublethal concentration of alachlor. In the present study the destruction of renal tissue was moderate however; there was a market increase in the level of destruction on cell with increase in the period of exposure. The results of the study indicate that even sublethal concentration of Ekalux is enough to elicit significant histological alterations in liver and kidney of A. testudineus. 
LIVER

A. CONTROL

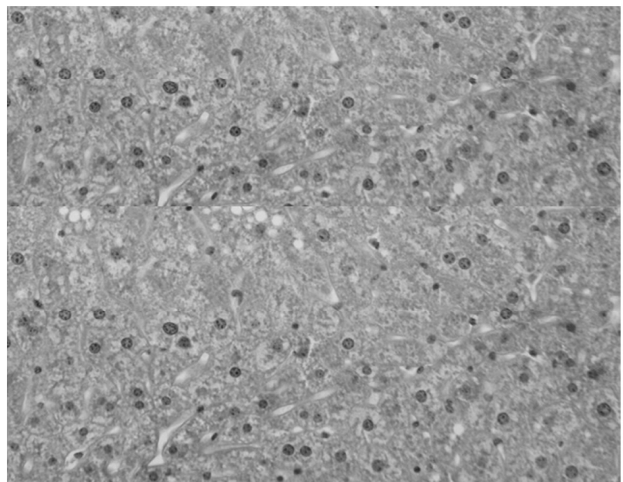

B. 15-DAY EXPOSURE

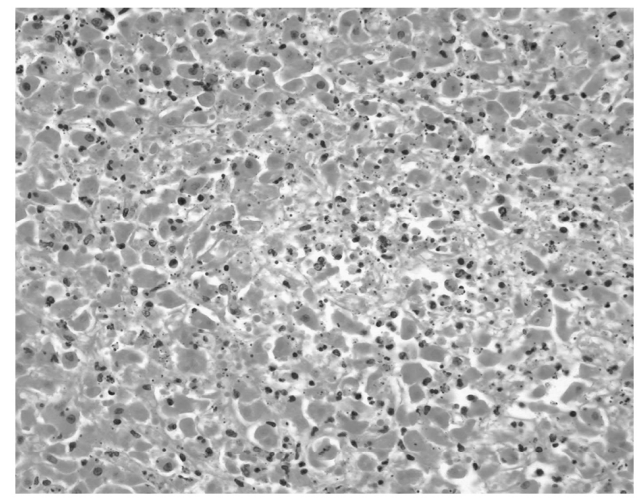

C. REVIVAL AFTER 6 MONTHS

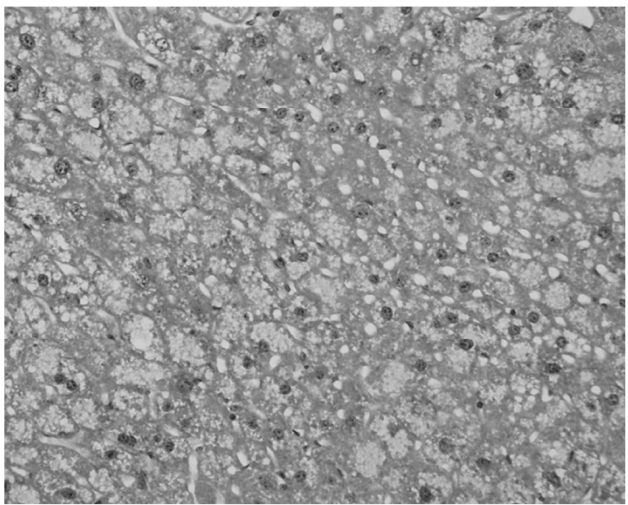

KIDNEY

A. CONTROL

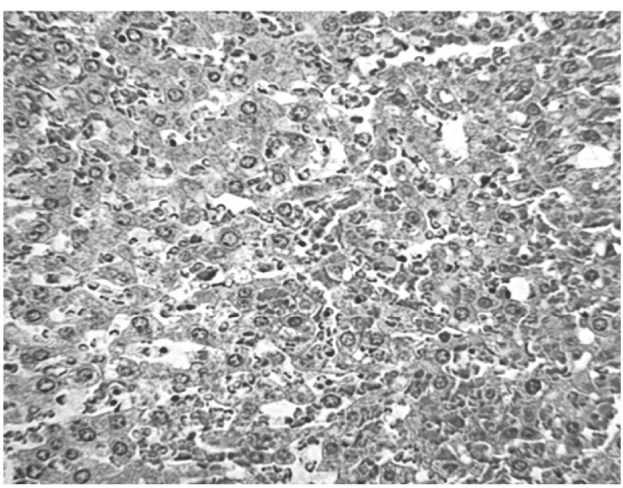

B. 15-DAY EXPOSURE

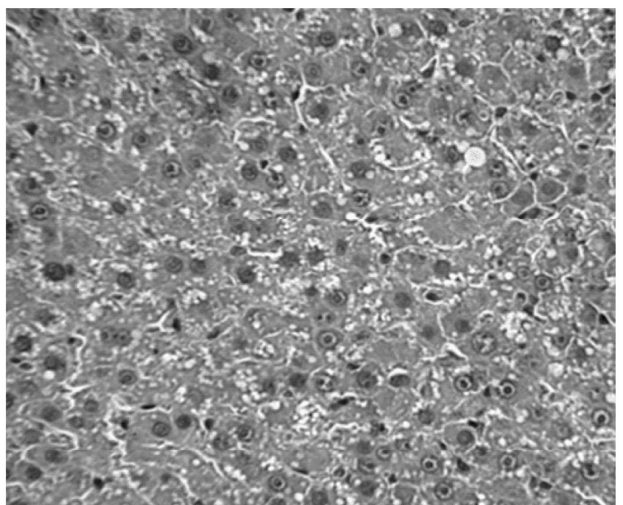

C. REVIVAL AFTER 6 MONTHS

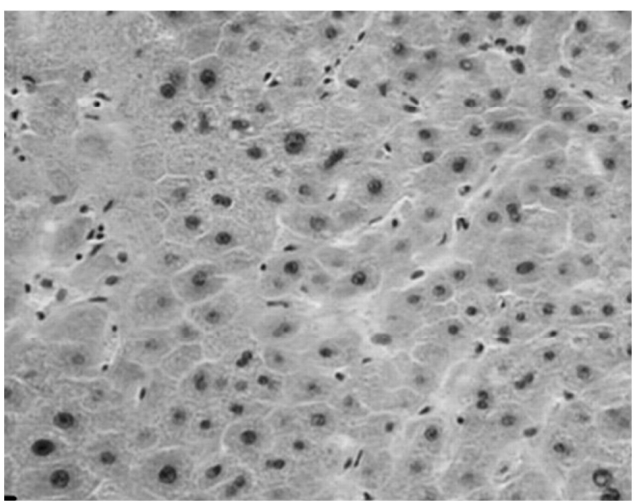

Figure 4. Histopathological investigation of Ekalux toxicity in Liver and Renal tissues of Anabas testudineus

\section{Conclusion}

The results of the present study clearly indicated that pesticides have a direct impact on the biochemical, physiological and structural alterations in sub adults of Anabas testudineus. Ekalux is known to impair the metabolic and the physiological activities of the organism. The results emerging from the present study also points out to the fact 
that through repeated exposure the pesticides tend to accumulate in tissues of animals even at sub lethal concentration. The alterations in the histology of liver and renal tissue seen in the present study is indicative of the fact that unlike bioaccumulation in terrestrial animals which is less relevant, in aquatic environment the impact is manifold. The study also affirms the view that histopathological analysis is a suitable method in toxicological studies to understand the pathological conditions of tissues under stress. Haematological and biochemical studies clearly indicates that through effective mitigation steps and proper management of our ecosystem the negative impact of pesticide toxicity on fishes could be reduced to certain levels. It is also suggestive that these type of toxicological studies are highly required to monitor the aquatic system and to assess the toxic effect of pesticides on aquatic organisms particularly fish.

Acknowledgements. We thank Dr. M. Razia Beevi, Head, Department of Aquaculture and Fishery Microbiology, MES Ponnani College for the suggestions and help during the process of the work. We would like to thank Prof. V.K.Baby, Principal for providing the necessary facilities for the study. The Help rendered by Dr. T.K. Maqbool and Dr. S. Sureshkumar is also deeply acknowledged.

\section{REFERENCES}

[1] Abraham, K.M., Thomas, T.V., Rekha, A (2003): Toxic and histopathological effect of Neemx on Anabas testudineus (Pisces). - Ecology and Noospherology 14: 55-61.

[2] Ahammed, F., Ali, S.S., Shakoori, A.R. (1999): Sublethal effects of Danitol (Fenpropathrin), a synthetic pyrethroid on freshwater Chinese grass carp, Ctenopharyngodon idella. - Folia Biologica 43: 151-159.

[3] Altinok, I., Capkin, E. (2007): Histopathology of Rainbow trout exposed to sublethal concentrations of Methiacarb or Endosulfan. - Toxicologic Pathology 35: 405-410.

[4] Beena, S., Viswarajan, S. (1987): Effect of Cadmium and Mercury on the haematological parameters of the fish Cyprinus carpion. - Environmental Ecology 5: 726-732.

[5] Blaxhall, P.C., Dansel, K.W. (1973): Routine haematological methods for use with fish blood. - Journal of Fish Biology 5: 771-781.

[6] Burton, K. (1956): A study of the conditions and mechanism of the diphenylamine reaction for the colorimetric estimation of deoxyribonucleic acid. - Biochemical Journal 62(2): 315-323.

[7] Butchiram, M.S., Tilak, K.S., Raju, P.W. (2009): Studies on histopathological changes in the gill liver and kidney of Channa punctatus (Bloch) exposed to Alachlor. - Journal of Environmental Biology 30(2): 303-306.

[8] Capkin, E., Altinok, I., Karahan, S. (2006): Water quality and fish size affect toxicity of Endosulfan, an organochlorine pesticide, to rainbow trout. - Chemosphere 64: 17931800.

[9] Das, B.K., Mukherjee, S.C. (1997): Variation of nucleic acid content in Labeo rohita exposed to sub lethal concentration of Malathion. - Journal of Applied Zoology 8: 145146.

[10] Gomez, K.A., Gomez, A.A. (1984): Statistical Procedures for Agricultural Research. $2^{\text {nd }}$ edn. John Wiley and Sons, New York, USA.

[11] Grant, B.F., Mehrle, P.M. (1973): Endrin toxicosis in rainbow trout (Salmo gairaneri). Journal of Fisheries Research Board of Canada 30: 31-38.

[12] Hesser, E.F. (1960): Methods for routine fish haematology. - Progressive Fish Culturist 22(4): 164-170.

[13] Hiroshi, I. (1962): Determination of pyrimidine ribonucleosides and nueleotides with the orcinol reaction. - Analytical Biochemistry 3: 186-193. 
[14] Jagoe, C.H. (1996): Responses at the tissue level: Qualitative methods in histopathology applied to Ecotoxicology. - In: Newman, M.C., Jagoe, C.H. (ed.) Ecotoxicology. A Hierarchial Treatment, Lewis Pub., CRC Press, New York, USA, 137-148.

[15] Koundinya, P.R., Ramamurti, R. (1979): Haematological studies in Tilapia mossambica exposed to lethal concentration of Sumithion and Sevin. - Current Science 48: 877-879.

[16] Lowry, O.H., Rosebrough, N.J., Farr, A.L., Randal, R.J. (1951): Protein measurement with the Folin-Phenol reagents. - Journal of Biological Chemistry 193: 265-275.

[17] Murty, A.S., Devi, P. (1982): The effect of Endosulfan and its isomers on tissue protein, glycogen and lipids in the fish Channa punctatus. - Pesticide Biochemistry and Physiology 17: 280-286.

[18] Musa, S.O., Omoregie, E. (1999): Haematological changes in the mud fish Clarius gariepinus exposed to Malachite green. - Journal of Aquatic Sciences 14: 37-42.

[19] Naidu, K.R.P., Kumari, J.P., Naidu, B.P. (1989): Impact of Endosulfan on the haematology of the fish Cyprinus carpio. - Environmental Ecology 5(4): 713-716.

[20] Narayan Ram, R., Sathyanesan, G. (1986): Organophosphate induced biochemical changes in brain, liver and ovary of the fish Channa puctatus (Bloch). - Proceedings of Indian National Science Academy, Part B: 67-71.

[21] Ravinder, V., Suryanarayana, N. (1988): Decis induced biochemical alterations in a freshwater cat fish, Clarius batrachus. - Indian Journal of Comparative Animal Physiology 6: 5-12.

[22] Reddy, P.M., Bashamohideen, M. (1989): Fenvalerate and Cypermethrin induced changes in the haematological parameters of Cyprinus carpio. - Acta Hydrochimica et Hydrobiologica 17: 101-107.

[23] Reddy, A.N., Venugopal, N.B.R.K., Reddy, S.L.V. (1991): Effect of Endosulfan 35 EC on certain aspects of protein metabolism in various tissues of a freshwater field crab, Barytelphura guerini. - Pesticide Biochemistry and Physiology 39: 121-127.

[24] Santhakumar, M., Balaji, M., Ramudu, K. (1999): Effect of sub lethal concentrations of Monocrotophos on erythropoietic activity and certain haematological parameters of fish Anabas testudineus - Bulletin of Environmental Contamination and Toxicology 63: 379384.

[25] Sastry, K.V., Sharma, S.K. (1979): Endrin induced hepatic injury in Channa punctatus (Ham). - Indian Journal of Fisheries 26: 250-253.

[26] Tripathi, P.K., Singh, A. (2003): Toxic effect of dimethoate and carabaryl pesticides on metabolism of the freshwater snail Lymnaea accuminata. - Bulletin of Environmental Contamination and Toxicology 70: 146-152.

[27] Wedemeyer, C.A., Yasutake, W.T. (1977): Clinical methods for the assessment of the effects of environmental stress on fish health. - US Tech. Pap., U.S. Fish and Wildlife Service 89: 1-18.

[28] Yasmeen, R., Tulasi, S.J., Ramana Rao, J.V. (1991): Metabolic changes in the airbreathing fish Anabas scandens on long-term exposure to endosulfan. - Pesticide Biochemistry and Physiology 40(3): 205-211.

[29] Yemm, E.W., Cocking, E.C. (1955): The determination of amino acids with ninhydrin. Analyst 80: 209-214. 